\title{
Indonesia's New Deposit Guarantee Law
}

\author{
Ross H. McLeod \\ Indonesia Project, Division of Economics \\ Research School of Pacific and Asian Studies \\ Australian National University
}

ross.mcleod@anu.edu.au

August 2005

\begin{abstract}
The blanket guarantee introduced in 1998 in response to the emerging banking and economic crisis resulted in $\$ 50$ billion of losses to the general public. The government has now introduced a law that enables the phasing out of this blanket guarantee, but which also allows for its reinstatement in the event of any threatened collapse of the banking system. Rather than eliminating the possibility of any repetition of the previous banking disaster, the new law effectively mandates an almost identical approach to handling system-wide banking collapses in the future, suggesting that the authorities and their advisers learned very little from the recent bitter experience. It is argued here that the crucial starting point for formulating policy in this field is to correctly specify the exact purpose that government intervention is intended to serve: namely, the avoidance of major macroeconomic disruption as a result of bank failures.
\end{abstract}

Key words: banking, bailout, deposit guarantee, deposit insurance, moral hazard JEL Classification: E42, E44, G21, G28 


\title{
Indonesia's New Deposit Guarantee Law
}

\author{
Ross H. McLeod
}

\section{INTRODUCTION}

What is the purpose of a guarantee of bank deposits? Deposit guarantee funds began to be established by various state governments in the US in the late 1800s and early 1900s (Thies and Gerlowski 1989). These interventionist schemes were presumably motivated by the desire of paternalistic governments to protect their citizens from financial calamity in the form of bank failures leading to the loss of their accumulated savings. That is, the objective was to protect individuals against the loss of their assets. The banks participating in these schemes paid a flat rate premium, based on the size of their customers' deposits, into the guarantee fund, which then reimbursed depositors of banks that failed.

But then, in the 1930s, as a direct consequence of the Great Depression, people saw in deposit guarantee funds (or deposit insurance) the possibility of removing runs on banks as a source of economic instability. A key feature of the Depression was that people lost confidence in the banks and rushed to withdraw their deposits. This resulted in a rapid fall in the money supply and a consequent drastic squeeze on the economy as banks and other entities tried to sell stocks of goods and other assets quickly in order to generate liquidity. The further consequence was a very high level of long-lasting unemployment and misery for those who lost their jobs. Deposit insurance schemes established around this time were based on the reasoning that if deposits were guaranteed, people would have no reason to rush to withdraw deposits from banks, even if there were signs that the banks were in danger of becoming insolvent. In this manner it would be possible to avoid any sudden reduction in the money supply, and thus to avoid any rapid contraction of economic activity that might otherwise result from this. Thus the purpose shifted to become protecting the national economy against disruption, with the aim of avoiding loss of income by individuals potentially put out of work as a result of a severe downturn in the business cycle, rather than loss of assets by individuals. In other words, there was a switch in the focus of deposit guarantees or deposit insurance from micro- to macroeconomic considerations. 
Years later, in the post-World War II era, the economics profession became increasingly uncomfortable with this form of interventionism, and searched around for some suitable market failure rationale that could justify it. Such a rationale could be found in the concept of 'asymmetric information' according to which depositors were supposedly unable to monitor the financial condition of banks for themselves, so that regulators could feel justified in providing them with (compulsory) insurance cover. The regulators could argue that they were simply correcting a market failure in the form of the imperfect or inadequate information available to depositors. Having decided to provide deposit insurance, this also provided a rationale for even more detailed regulation and supervision of banks, so that the regulators would have ready access to the information that depositors could not obtain themselves, allowing the regulators to push for corrective action on behalf of depositors, and on behalf of the deposit insurance institution.

Economists had long been concerned also, however, about the moral hazard problem inherent in guarantees of deposits (as with all forms of insurance). By protecting depositors against losses that may be incurred by their banks, the discipline that depositors would otherwise impose on banks was greatly weakened, thus reducing the disincentive for banks to undertake excessively risky lending and increasing their incentive for better management. Of course, the moral hazard problem only makes sense if depositors are actually well informed of their banks' activities and condition (in contrast with the asymmetric information view that sees them as largely ignorant), and if they act on this knowledge-or fail to act, if their deposits are guaranteed. Thus the dominant view came to be that large depositors had, or could easily obtain, such knowledge, and that therefore they did not need protection: they were big enough and sophisticated enough to be able to inform themselves as to whether particular banks were healthy or not. For this reason it was considered unnecessary to protect large depositors and, perhaps, that it was desirable to keep them exposed to risk; deposit guarantees therefore came to be restricted to small deposits.

This brings us back to the opening question: what is the purpose of guarantees of deposits? With the restriction of guarantees to small deposits, the rationalisation of the guarantee of bank deposits shifted its focus, perhaps without anybody realising it, back to the protection of depositors' assets rather than protecting the national economy from the severe downturns in the business cycle. But, in contrast to the guarantee funds that existed a century ago, these days it is only small depositors that 
are seen as worthy or needful of being protected by this mechanism ${ }^{1}$ (at least in those countries that have a deposit insurance system). ${ }^{2}$

This meant that deposit guarantees, as a mechanism to guard against bank runs and the ensuing economic disturbance, had been seriously compromised. Large depositors now found themselves with little or no cover, and so they could be expected to run if there was a hint of trouble at their bank. This reality was eventually brought home with the failure of Continental Illinois Bank in the US in 1984 (Sprague 1986: 32). It was this and other similar episodes around the same time that generated the idea of 'too big to fail'. Despite the fact that the Federal Deposit Insurance Corporation only insured deposits up to the value of $\$ 100,000$, when the big depositors and other creditors started running away from Continental Illinois, it was quickly decided to raise the cover to $100 \%$ because the bank was believed to be 'too big to fail'.

The confusion apparent in policy making in relation to deposit guarantees and insurance reflects the inherent conflicts between the two basic objectives of such arrangements (Table 1). On the one hand, there is the desire to protect depositors; on the other, there is the desire to protect the general public. Having chosen to guarantee deposits, the choice must then be made whether to protect all, or only small, deposits. If all deposits are protected, this creates enormous moral hazard problems, significantly increasing the likelihood that there will be widespread bank collapses as a result of excessive risk-taking and fraudulent behaviour on the part of management.

Since the government is the ultimate guarantor, such collapses are very likely to impose huge budgetary costs, which will have their impact on the general public in the form of some combination of higher taxes and reduced provision of government services. If it is decided instead to protect only the small deposits, this will leave the banking system open to destabilising mass deposit withdrawals if there is any kind of shock that threatens the solvency of banks. In such circumstances, large depositors that are not covered by the guarantee will be quick to withdraw their funds and then shift them to safer havens. This, in turn, may result in considerable disruption to the

${ }^{1}$ By far the majority of countries with deposit insurance schemes restrict coverage to 'small' depositors, though the monetary amount that defines 'small' differs very widely (Demirgüç-Kunt $e t$ al. 2005).

${ }^{2}$ Roughly half of the 182 countries contained in the World Bank's deposit insurance schemes database (Demirgüç-Kunt et al. 2005) do not have explicit deposit insurance schemes. High income countries included in this category include Australia, New Zealand, Hong Kong and Singapore. 
normal flow of economic activity, with a consequent increase in unemployment and decrease in individual incomes. There seems no obvious way entirely to resolve this conflict, which seems inherent in deposit guarantee schemes. The new Indonesian scheme turns out to be no exception, as we shall see.

Table 1 Inherent Conflicts in Deposit Guarantees and Insurance

\section{Objective I: Protect depositors}

\section{Choices}

\section{Problems}

moral hazard

bank runs

\section{Damage}

economy

budget all

small

yes

\section{Objective II: Protect Public}

taxes up/services down

loss of income/unemployment yes

$\begin{array}{ll}\text { yes } \\ \text { yes } & \text { yes }\end{array}$

yes

The remainder of this paper is structured as follows. The next section reviews the 1997-99 banking collapse in Indonesia, which provided the catalyst for the introduction of the new legislation discussed here. This is followed by a description and evaluation of this legislation, and then by a discussion of alternative approaches to promoting a more healthy banking system and handling bank failures. The concluding section sets Indonesia's new deposit guarantee legislation in the context of an interpretation of the history of deposit guarantees/insurance.

\section{INDONESIA'S GREAT BANKING DISASTER OF 1997-99}

The disastrous collapse of Indonesia's banking system in 1997-99 provides a clear illustration of the harm done by having conflicting objectives of banking policy. The collapse has been well documented elsewhere (e.g. Enoch et al. 2002; Fane and McLeod 2002; Pangestu and Habir 2002; Djiwandono 2004; Frécaut 2004), and may be summarised as follows. At the beginning of November 1997 the government decided to close 16 small banks. Despite having said on several occasions prior to the crisis that it provided no guarantee of bank deposits, it now announced that it would guarantee deposits at those banks up to a maximum value of Rp 20 million per depositor. The implication was that larger deposits in the remaining banks were not 
guaranteed. Since there was a considerable volume of much larger deposits in the banking system - in particular, in private domestic banks - this action resulted in a rush of withdrawals from these banks, many of which were widely believed to be in poor financial condition. Thus the desire to protect the assets of only small depositors immediately came into conflict with the imperative of stabilising the economy.

\section{Moral hazard takes over}

In the face of this enormous rush on the domestic, privately-owned banks, the government decided to announce a blanket guarantee of banks' obligations. Thus the system had gone from no guarantee to a guarantee of small deposits to blanket coverage of all deposits in the space of less than three months. This created a severe moral hazard problem, since depositors now had almost no reason to worry about whether their banks were engaging in risky behaviour. On the other hand, in the absence of any market discipline from depositors the owners and managers of those banks had every reason to take on high risks. Their banks were probably already insolvent, since the huge devaluation of the rupiah had made many of their borrowers incapable of repaying their loans. They therefore had little or nothing to lose, and much to gain-especially when there appeared to be strong prospects for huge gains from currency speculation. If they could undertake some successful gambles they might recoup their losses, and perhaps even come out in front. Alternatively, they could simply involve themselves in fraudulent and other illegal behaviour (or increase their involvement), such as making large, inadequately secured loans to affiliated entities, without needing to worry about any negative response from the market.

Indeed, several banks, including many very large ones, began to make large new loans (in conditions of economic crisis, when great caution would have been far more appropriate), mainly to their own affiliates. The borrowers then used these loans to speculate against the rupiah or to repay their foreign currency borrowings (which is much the same thing, since both actions are motivated by expected devaluation of the currency, and both have the same macroeconomic impacts). These purchases of foreign currency, directly or indirectly from the central bank (Bank Indonesia, BI), caused the banks in question to experience severe liquidity shortages, whereupon they turned to BI for assistance. Acting as lender of last resort, BI thus found itself supplying both the liquidity needed to be able to make such loans (known by its Indonesian acronym BLBI: Bantuan Likwiditas Bank Indonesia), and the foreign exchange that the borrowers wanted to buy (Figure 1). An inescapable conclusion is that the severity of Indonesia's crisis had a great deal to do with this 
egregious breakdown in the conduct of macroeconomic (monetary and exchange rate) policy. The important question now (to which we shall return) is whether the new deposit guarantee arrangements will help to avoid such an outcome in the future. To put it differently, was the crisis caused or exacerbated by lack of a formal deposit guarantee scheme-or by its introduction?

Figure 1 Bank Indonesia Financing of Currency Speculation

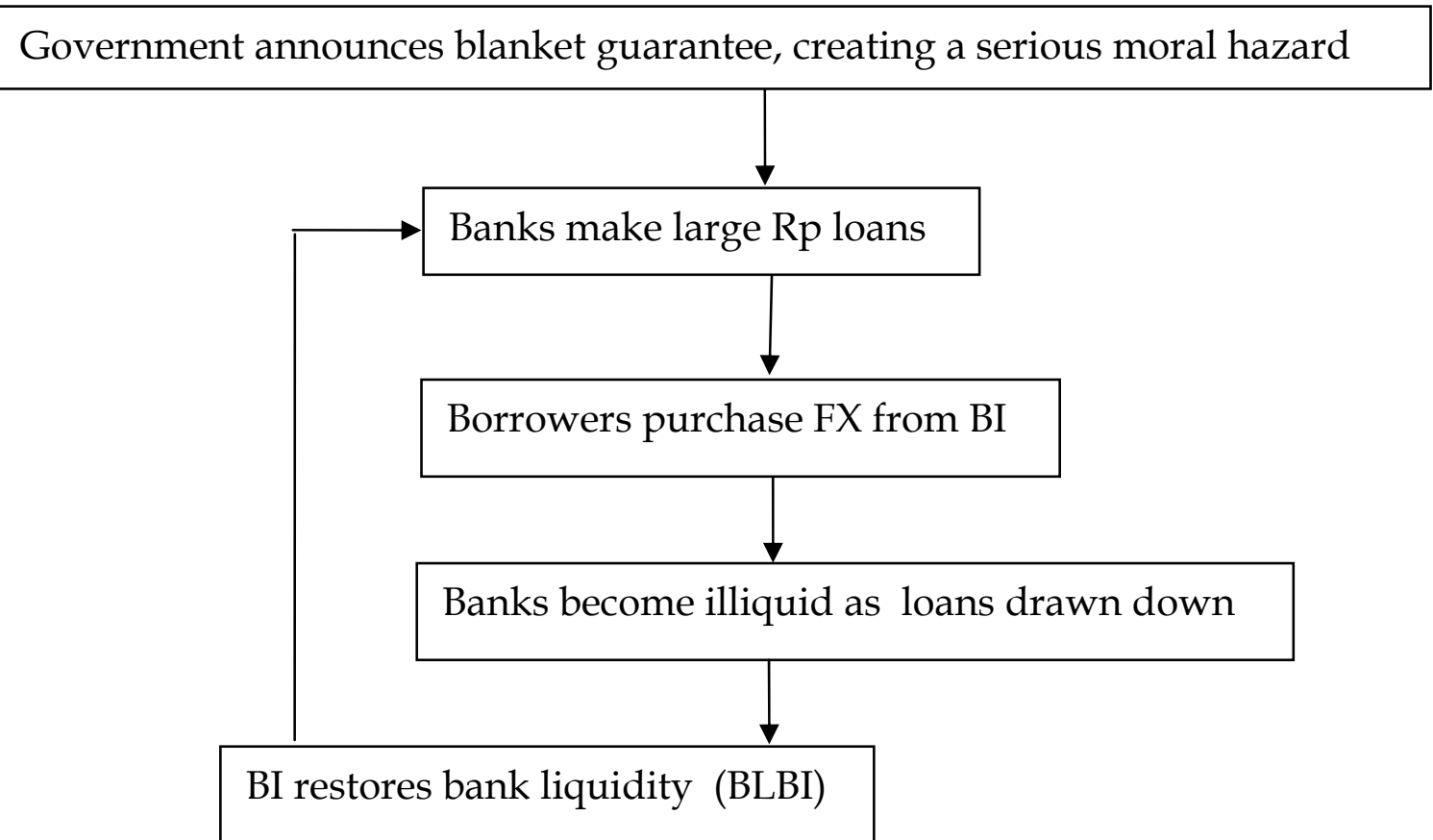

\section{IBRA}

The Indonesian Bank Restructuring Agency, IBRA, began to be established early in 1998. Its job was basically to clean up the banking system, and it was given a limited period of six years in which to do so. Within a couple of months, some big private banks had been closed (Johnson 1998: 47-9). Every remaining bank was subjected to a new audit, following which an additional large number were closed. Many others that had become insolvent (but to a lesser extent) were taken over by the government. These were banks that were perceived as 'too big to fail': in other words, they were regarded as systemically important, such that their failure would have a significant negative impact on the national economy. In some of these cases, the original shareholders agreed to make a new capital injection, which was permitted provided that they ended up owning at least $20 \%$ of the shares of the bank in question. For all of the banks that were to be rehabilitated, the government 
(sometimes in concert with the original owners) injected sufficient new capital to cover past losses and to achieve a capital adequacy ratio (CAR) of at least $4 \% .^{3}$

IBRA now was given four functions:

1 to manage, and to liquidate the assets of, banks that had been closed (the liabilities having been transferred to the various state banks, which were compensated either with cash from the central bank or bonds from the government)

2 to take over the worst category of non-performing loans from the state banks and from private banks that had been taken over (in whole or part) by the government

3 to manage and to liquidate assets that had been surrendered by their original owners in lieu of repayments in cash of last resort loans from the central bank (BLBI) to their banks.

IBRA's ultimate task was to recover as much cash as possible from the sale of these assets and/or shares in the banks in question. IBRA was eventually closed down after six years, as originally intended, even though it had not completed its work. Making some allowance for further asset recoveries by the finance ministry after its closure, IBRA will have managed to recover about $25 \%$ of the cost to the government of covering banks' losses in order to bail out depositors (McLeod 2005a). The net cost to the government is of the order of $\$ 50$ billion, or about $40 \%$ of annual GDP (Fane and McLeod 2002; Frécaut 2004). ${ }^{4}$ This cost has been met by the issue of new government bonds that are being amortised over a period of around two decades, at the expense of some combination of reduced government provision of services to the public, reduced spending on infrastructure, and increased taxation.

This brief outline of how the banking collapse unfolded, how it was handled, and how the general public are suffering as a result of the costs incurred by the government clearly illustrates the inherent conflict in deposit guarantees as summarised in table 1. The government's initial response to problems in the banking sector was to guarantee small deposits in the banks it closed, leaving other depositors to draw the implication that deposits in the remaining banks were at best guaranteed at the same relatively low level. Large depositors then began to desert

\footnotetext{
${ }^{3} \mathrm{CAR}$ is the ratio of capital to risk-weighted assets.

${ }^{4}$ Understandably, perhaps, the government of the day chose not to report a budget deficit of the order of $40 \%$ of GDP, although this is exactly what was implied by the bailout.
} 
the private banks in droves, to which the government responded by extending its guarantee to cover all deposits. But this generated a moral hazard problem of such magnitude that many other banks, including all the large domestic banks, quickly became insolvent, in many cases deeply so. The government's contingent liability turned out to be far greater than had been anticipated when the blanket guarantee was announced in January 1998. The new law discussed here is the (Megawati) government's, and Bank Indonesia's, collective response to this financial calamity.

\section{THE NEW LAW}

At the end of October 1997, in the first of a series of Letters of Intent from the government to the IMF, the government committed itself to setting up some kind of deposit insurance arrangement during the period of crisis assistance by the IMF (GOI 1997). In the event, this program ran its course by the end of 2003 without achieving this particular target. Legislation was finally passed in September 2004 to set up a Deposit Guarantee Institution (DGI, Lembaga Penjamin Simpanan), thus allowing the phasing out of the blanket guarantee (GOI 2004).

\section{Broad outline}

The DGI will be fully owned by the government, which is to subscribe its initial capital of $\operatorname{Rp} 4-8$ trillion. ${ }^{5}$ It will charge a premium to all banks (for which participation is compulsory) at a common rate set initially at $0.2 \%$ p.a., based on the level of their customers' deposits. ${ }^{6}$ (There is scope for differentiation of this premium amongst banks in accordance with their perceived riskiness, although the difference between the highest and lowest premium may not exceed 1\% p.a.) Premium income will be used to build up a reserve against future claims on the guarantee. Additional income will be earned from the investment of this reserve and the initial capital. When, or if, the reserve can be built up to a target level equivalent to $2.5 \%$ of total deposits, the premium can be adjusted downward so as to maintain reserves at that level. The scheme itself will not become operational until 18 months after enactment of the law, and it will be a further 18 months again before the limit on the size of deposits to be guaranteed falls to its ultimate level of Rp 100 million by way of a series of six-monthly reductions of the guarantee cover (table 2).

\footnotetext{
${ }^{5}$ The exact amount within this range is to be determined in consultation with the parliament.

${ }^{6}$ The decision to set the rate at $0.2 \%$ appears to have been essentially arbitrary. Such premia vary enormously around the world (for example: India and Korea $0.05 \%$; Ecuador 0.65\%) (Demirgüç-Kunt et al. 2005).
} 
Table 2 Phased Reduction of Deposit Guarantee Coverage

\section{Coverage of deposits}

$100 \%$ (existing blanket cover)

Rp 5 billion

Rp 1 billion

Rp 100 million

\section{Period}

until March 2006

April-September 2006

October 2006-March 2007

from September 2007

The elucidation of the law states that

the value that is guaranteed is hoped to protect all deposits owned by small depositors, who represent the majority of bank customers in Indonesia. ${ }^{7}$

This turns out to be something of an understatement. Recent data suggest that almost all deposits (98.3\%) are in amounts of less than Rp 100 million (table 3), so the new arrangements will certainly provide full protection for virtually all depositors. However, if we focus on value rather than number of deposits, we find that less than one third (32.1\%) of the total value is accounted for by deposits of less than Rp 100 million. It would appear, therefore, at least at first glance, that the new arrangements will be quite incapable of preventing bank runs, since the large deposits not covered by the guarantee comprise over two thirds of the aggregate of all deposits (table 3). Recall that these were precisely the circumstances that led to the rush on the banks following the initial closures in November 1997, when only small deposits (up to Rp 20 million) were guaranteed by the government.

The rationale for the new law is set out in the preamble to its elucidation, which draws heavily on Indonesia's experience with the drastic collapse of the banking system during 1997-99. But the authors could just as well have been talking about the US at the time of the Great Depression:

The stability of the banking industry strongly influences the stability of the economy as a whole, as demonstrated by the experience of the monetary and banking crisis in Indonesia in 1998...

Confidence on the part of the general public towards the national banking industry is a key to safeguarding its stability, such that a crisis such as this

\footnotetext{
7 This and other translations of parts of the law and its elucidation are by the author.
} 
will not be repeated. This confidence can be achieved through legal certainty in the regulation and supervision of banks, together with a guarantee of bank deposits to improve the continuity of healthy banking business. The continuity of healthy banking business can guarantee the safety of the deposits of the banks' customers... ${ }^{8}$

\begin{tabular}{ccc} 
Table 3 Size Distribution of Bank Deposits (\%) \\
Size range & \multicolumn{2}{c}{ Cumulative totals } \\
\cline { 2 - 3 } Rp million & Number & Amount \\
$<7.5$ & 87.7 & 5.2 \\
$7.5-10$ & 88.3 & 5.6 \\
$10-25$ & 93.4 & 12.7 \\
$25-50$ & 96.3 & 21.3 \\
$50-100$ & 98.3 & 32.1 \\
\hline $100-500$ & 99.8 & 56.1 \\
$500-1,000$ & 99.9 & 62.3 \\
$1,000-5,000$ & 100.0 & 76.7 \\
$>5,000$ & 100.0 & 100.0
\end{tabular}

Source: Data kindly supplied by Bank Indonesia

It is astonishing that the lessons of the recent banking collapse can have been so easily forgotten. In particular, the statement that '... confidence can be achieved through legal certainty in the regulation and supervision of banks, together with a guarantee of bank deposits...' can be seen to be nothing more than wishful thinking when interpreted in the light of the data presented in table 3. A guarantee that covers only a third of the value of deposits cannot be effective in preventing bank runs. Moreover, it is likely to be quite some time before the community will feel confident about the regulation and supervision of banks. As Fane has pointed out, commentators

... expressed at least guarded praise for [prudential] controls... [long before the crisis, but it] turned out that there had been a chasm between the controls that existed on paper and those that were actually implemented... Fane (1998: 299)

\footnotetext{
8 Note that the logic here is confused. The introduction of moral hazard as a result of deposit guarantees is actually likely to harm the health of the banking sector, even though it may protect it from disruptive bank runs.
} 
Indeed, prudential regulation and supervision seems no more effective now than it had been before the crisis, as suggested by various recent banking scandals and associated closures (Kenward 2004: 26; Soesastro and Atje 2005: 22-3; McLeod 2005b: 152).

The preamble to the law demonstrates at least some awareness of the moral hazard problem-especially if the guarantee is very broad-and its implications for the government's budget:

The blanket guarantee of the banks' obligations, based on the earlier Presidential Instruction, ${ }^{9}$ was successful in restoring the confidence of the public in the banking industry during the monetary and banking crisis. Nevertheless this very broad guarantee also burdened the state budget, and gave rise to moral hazard on the part of the managers and customers of banks. The managers were not given an incentive to manage the banks prudently, while the banks' customers did not pay attention to, or consider important, the financial condition of the bank when undertaking transactions with it.

All this is followed up with an optimistic statement about what the law hopes to achieve-a further example of wishful thinking that betrays a lack of appreciation for the inherent conflict in deposit guarantees as described above:

This law provides for a guarantee to bank depositors, which it is hoped will be able to safeguard the confidence of the public towards the banking industry, and to minimise the risk of burdening the state budget or the risk of emergence of moral hazard.

The main text of the law prescribes two functions for the proposed DGI: first, guaranteeing bank customers' deposits (reflecting what has been described above as a paternalistic desire to protect depositors); and second, helping to safeguard the stability of the monetary and banking system and, on occasion, the economy (reflecting the macroeconomic imperative of avoiding, or ameliorating the impact of, business cycles). These two functions seem clearly to be regarded as independent of each other. In particular, the guarantee of deposits is seen as an end in itself: protecting the assets of depositors. Thus the law does not argue that the function of

\footnotetext{
9 Interestingly, there is no formal, specific reference to this in the list of relevant laws and regulations that always precede the text of Indonesian laws. Presumably the reference here is to the presidential instruction issued in January 1998, announcing the blanket guarantee.
} 
the DGI is to guarantee the safety of the bank customers' deposits in order that depositors will never have any reason to rush to withdraw their funds from banks (because of fears about solvency, thus removing the possibility of bank runs as a source of an economic instability). The depositor protection rationale is most clearly evident in the decision to extend coverage to deposits with the so-called secondary banks (bank perkreditan rakyat) - several thousand very small banks, the defining characteristic of which is that they are excluded from the national payments system. Failure of these banks would pose no threat to the stability of the banking system or the economy.

\section{Operational features}

When small banks fail: an inbuilt bias toward closure

The mode of operation of the DGI is fairly straightforward in the case of failure of small banks that are of little importance individually to the economy. The Bank Supervision Institution (BSI, currently the central bank) first does all that it can within its own authority and powers to correct the problems of troubled banks. But if it has exhausted all avenues open to it without success, it then refers the bank in question to the DGI, which then decides whether it will rehabilitate or liquidate it.

If it is decided to liquidate the bank, the DGI ensures that deposits up to a limit of Rp 100 million per customer are repaid. ${ }^{10}$ Repayment of deposits in excess of this limit must await the generation of cash during the liquidation process. Larger deposits will only be repaid to the extent that the bank's remaining assets generate sufficient revenue for this purpose, after meeting the costs of the DGI. The DGI will not lose any of its reserves in such cases, since losses of the bank will be absorbed by others: first, the shareholders, and then the large depositors. Rehabilitation, on the other hand, requires the DGI to make up the difference between total liabilities (excluding shareholders' funds and subordinated loans) and the going concern value of the bank's assets.

The choice between liquidation and rehabilitation is to be based on the principle of minimising the cost to the DGI. Ignoring expenses incurred during these processes (such as legal and auction expenses) for simplicity, the cost under the liquidation option is the difference between the value of guaranteed deposits and the liquidation value of the bank's assets. The corresponding cost under the rehabilitation option is the difference between the value of all third party liabilities and the going concern

\footnotetext{
${ }^{10}$ Recall, however, that there is a phasing-in period during which larger deposits are guaranteed.
} 
value of the bank's assets, this being the amount that needs to be injected in order to restore equity from negative to zero. ${ }^{11}$ The rehabilitation option will only be chosen, therefore, if the bank has a relatively large amount of guaranteed deposits, or if there is a large difference between the going concern value and the liquidation value of its assets.

Note that what is good for the finances of the DGI is different from what is good for Indonesian society as a whole. The discrepancy between the going concern value and the liquidation value of a bank's assets reflects the cost to society if the bank is closed. This cost arises because liquidation necessarily involves the dissipation of assets that are specific to the bank in question, and are therefore lost if the bank disappears. Nothing in the law reflects this important point. In this respect, the law demonstrates that policy makers still do not appreciate this consequence of liquidating banks: scores of banks were liquidated during the previous crisis, including some very large ones. This necessarily involved the unnecessary wastage of considerable investment by the banks in question in intangible assets, not to mention the fact that many thousands of bank employees lost their jobs. As the writer has noted elsewhere (McLeod 2004: 101-2), this was a consequence of establishing criteria for liquidation of banks that focused primarily on their capital adequacy ratios (reflecting past performance), rather than on minimising the cost to the public of the bank rehabilitation program.

Table 4 shows a hypothetical example in which the DGI chooses liquidation, given that the cost to itself of repaying guaranteed deposits is less than the cost to it of covering past losses in order to keep the bank operating. It can be seen that this choice involves social waste, since the liquidation value of the bank's assets is considerably less than their going concern value. The new scheme is defective, therefore, in so far as it requires the DGI to follow a course of action that is unlikely to be in the best interests of society as a whole.

${ }^{11}$ Additional capital injections to generate positive capital are an investment, not a cost. 
Table 4 Choice Between Rehabilitation and Liquidation

Rehabilitation

Liquidation

$\begin{array}{lclc} & \mathrm{Rp} & \mathrm{Rp} \\ \text { All liabilities } & 100 & \text { Guaranteed deposits } & 40 \\ \text { Going concern value } & 60 & \text { Liquidation value } & 35 \\ \text { Cost to DGI } & 40 & \text { Cost to DGI } & 5 \\ \text { Social cost of liquidation (going concern value less liquidation value) } & 25\end{array}$

\section{More complex cases}

The operation of the scheme is quite different, however, in the case of 'systemically important' banks - that is, banks whose closure is believed would probably have a significant negative impact on the economy as a whole. ${ }^{12}$ The decision as to whether a bank is 'systemically important' is at the discretion of a coordination committee composed of the Minister of Finance and representatives of BI, the BSI, and the DGI (presumably, their respective heads or their nominated delegates). ${ }^{13}$ Once a bank is so designated, its closure and liquidation is ruled out. Instead, it is handed over to the DGI to be rehabilitated. In this case, the question of claims by depositors against the guarantee does not arise, since this can only be as a result of liquidation.

It follows that depositors - not just small depositors, but all depositors-are safe if their funds are placed in 'systemically important' banks. In effect, the law actually provides a blanket guarantee of all deposits in systemically important banks, despite the attempt to create the impression that it seeks only to protect small depositors. The writer's understanding is that there are about fifteen systemically important banks, which account for about three quarters of total bank deposits. Thus the new law does not only further postpone getting rid of the blanket guarantee, but actually makes very little progress in getting rid of it at all-even after the long phasing in period. Well in excess of three quarters of the value of all bank deposits will still, apparently, enjoy a $100 \%$ guarantee from the government. This is not to argue that

\footnotetext{
${ }^{12}$ It is surprising that this crucially important term is not defined in the law. The interpretation given here is obtained from a reading of the elucidation of the law.

${ }^{13}$ The law actually states that the committee's membership is comprised of the minister and 'BI, the BSI and the DGI'.
} 
rehabilitation is the wrong option, however. On the contrary: as argued above, this option avoids the social cost of unnecessary dissipation of bank-specific assets inherent in liquidation. Nevertheless, the severe moral hazard problem generated by this approach must be acknowledged, and a way to avoid it must be sought.

\section{System-wide bank runs}

In certain circumstances we can expect that there will be a rush to withdraw deposits from large numbers of banks simultaneously, as occurred in late 1997 and early 1998. In such circumstances the law allows the government to change the upper limit on the size of guaranteed deposits. Indonesia's experience in 1998 (and that of many other countries that have experienced banking crises: recall the case of Continental Illinois in the US, mentioned earlier) suggests clearly that the government is likely to respond to political pressures for bailouts by increasing this limit significantly, and quite likely to $100 \%$ (Fane 1998: 301). In other words, although the law purports to replace the current blanket guarantee, in fact it allows this to be reinstated whenever there is a threat to the banking system as a whole. The effect of this would be to create a severe moral hazard problem again, even at small banks that are not considered systemically important in normal circumstances.

\section{Implications}

It follows from all of this that although almost all depositors will be covered by the guarantee, the law achieves little, if anything, in relation to the important objective of minimising the moral hazard problem that is recognised in the legislation itself as a principal contributor to the previous banking collapse. Under this new law, and notwithstanding its optimistic self-justification, depositors will have little reason to impose any form of discipline on systemically important banks (that is, by shifting their deposits to other banks that are managed more prudently). Accordingly, the managers of these banks will have only weak incentives to avoid making excessively risky loans, or to fear the market response that would provide some constraint on fraudulent or otherwise illegal behaviour.

When the DGI rehabilitates a bank, it needs to draw down its guarantee reserves to provide the necessary injection of equity to cover the accumulated losses of that bank. If the losses are so large as to exhaust these reserves it must then draw on its own initial subscribed capital and, if this is still insufficient, it must then turn to the government to make up the difference. Recall that the targeted size of DGI reserves is $2.5 \%$ of total bank deposits. By contrast, the ultimate cost to the government of the 
late 1990s banking bailout was $136 \%$ of total deposits of the banking system in June 1997, just prior to the crisis! ${ }^{14}$

As the saying goes: those who fail to learn the lessons of history are destined to repeat it. In essence the new scheme almost exactly reflects the approach followed during the banking crisis of 1997-99, the main difference being that now there will be an institution already in existence ready to perform the functions for which IBRA was hurriedly established and given responsibility. Thus, rather than setting up a new set of arrangements that would minimise the possibility of the banking system again imposing huge costs on the state budget, this new law seems almost deliberately designed to encourage a repetition, by creating a huge contingent liability for the government.

\section{RETHINKING THE NEED FOR DEPOSIT GUARANTEES}

The enormous cost of Indonesia's banking collapse demands that policy makers design a set of arrangements that will minimise the likelihood of any similar crisis in the future. These arrangements should include two basic components: first, measures designed to keep the banking system healthy; and second, measures to deal properly with bank failures should they occur nevertheless. The discussion above suggests strongly that the DGI legislation is not the appropriate policy response. First, it does nothing to improve the health of the banks. On the contrary: it moves in precisely the opposite direction, by introducing (or failing to eliminate) a serious moral hazard problem. Second, it threatens a repeat of the costly bailouts of 1997-99 by imposing a contingent liability on the government as large as the sum of all liabilities of the banking system - around 44\% of GDP. ${ }^{15}$

\section{Strengthening the banking sector}

As has been argued elsewhere, there are at least two main ways in which the health of the banking system can be improved. First, banks can be required to adhere to much more stringent CAR requirements, given that it is shareholders' funds that provide the margin of safety for banks' depositors and other creditors. The higher this ratio, the greater the protection for creditors, and the greater the incentive of owners to ensure prudent management of the banks. Fane and McLeod (2002: 290-

\footnotetext{
14 According to Fane and McLeod (2002: 288), the net fiscal cost of the bailout was about Rp 384 trillion, while total bank deposits were only Rp 283 trillion in mid 1997.

15 This figure is calculated as total bank liabilities (excluding equity) in June 2004, divided by GDP in 2004.
} 
91) suggest that the minimum CAR should be at least $16 \%$ (rather than the current $8 \%)$.

Banks' owners would inevitably protest such a policy change, arguing that it would be difficult, if not impossible, for them to find the additional capital. In reality, all that is required is to persuade some current holders of, say, time deposits, to become shareholders instead, which can be achieved if the issue price of shares, relative to the interest rate on deposits, is sufficiently attractive. Alternatively, the current owners could generate the necessary funds by selling off some of their other business assets (which would have the desirable consequence of encouraging them to concentrate more fully on being bankers). Those that are unwilling or unable to follow courses of action such as these will need to shrink their banks' balance sheets over time, or sell their banks to new owners. This would hasten the process of consolidation of the banking system into a smaller number of larger banks (which the authorities regard as desirable), but nobody should be under any illusion that the banking system as a whole would shrivel up and die as a consequence of significantly higher capital adequacy requirements.

A second way to increase the health of the banking system is simply to encourage much greater participation by reputable foreign banks. The risks faced by such banks are far more highly diversified than those of domestic banks, and their capital resources are more than adequate to cover losses they might incur in the relatively small Indonesian market. In hindsight, the benefit of such a policy is obvious: the Indonesian government lost nothing whatsoever on the foreign and foreign joint venture banks during the late 1990s collapse. As a side benefit, the competitive stimulus foreign banks would offer to their domestic competitors, and the demonstration effect of more sophisticated management approaches to the banking business, would help to improve the quality of the banking system as a whole over time.

\section{Dealing with bank failures}

The main concern here, however, is how to deal with bank failures, since this eventuality cannot be entirely ruled out. It should be clear from the previous discussion that the first step is to clarify the appropriate objective. In the view of the writer, there is an important role for governments in trying to minimise the potentially severe macroeconomic consequences of bank failures, but there is no valid argument for protection of the value of bank deposits as an end in itself. Bank deposits are only one of a wide variety of forms in which the public can hold its 
wealth, and it is not sensible for the state to take over the responsibility for carefully managing this particular component.

In different context, there is a strong rationale for caveat emptor (let the buyer beware): it is simply not practicable for the state to look after all of our interests in a direct fashion when we are buying things. The best it can do is to provide indirect protection in the form of a legal environment in which buyers are able to hold suppliers to their promises. The same caveat emptor approach is equally sensible in relation to investment transactions: it is not practicable for the state to take on the role of looking after all of our interests in a direct fashion when we purchase assets. Thus nobody suggests that governments should intervene to protect the owners of business enterprises, shares, bonds, housing and other real estate, motor vehicles, consumer durables or gold against losses in value of these assets. It seems inconsistent, therefore, for governments to take on the responsibility of insuring individuals and organisations against the loss of value of a particular class of assets: namely, bank deposits. ${ }^{16}$

Moreover, it is not sensible for governments to go beyond providing an appropriate legal framework for protecting the general public by intervening in particular asset markets in ways that take away individual responsibility for monitoring and managing the risks involved. To do so is to create moral hazard, which implies the likelihood of unintended transfers of wealth from the general public to that segment of the general public that chooses to invest in the particular asset class on which the government chooses to focus. Moreover, this is potentially a regressive policyespecially in a country like Indonesia, in which bank deposits, broadly speaking, are owned by the middle and wealthy classes, but not by the very poor.

There is at least one argument running counter to these views that is worthy of consideration. This is the belief that economic development is assisted by a strong financial sector, and that this can be encouraged by having deposit insurance. In response to this, note first an important empirical issue yet to be settled: it is not clear that financial development causes economic development, or whether the causation runs in the opposite direction, or whether the causation runs both ways (Manning 2003). More important, however, is that even if it could be shown that

16 The government's concern to protect depositors against losses incurred as a result of holding commercial bank liabilities is not matched by a similar concern about those resulting from their holdings of a liability of the central bank: namely, cash. The authorities have a rather sorry record in this regard. For example, the value of cash fell by half in the first nine months of the recent crisis as a result of poor monetary policy. 
financial development causes economic development, this does not necessarily imply that encouraging financial development by artificial means-such as disguised subsidies in the form of government guarantees of bank deposits-is called for. The minimum requirement for this to be true is evidence that the rate of financial development is slower than optimal. The writer is unaware of any such evidence in Indonesia.

Such subsidies distort the structure of financial markets. It is no coincidence that bank finance has played a predominant role in financing investment in Indonesia at the expense of other financial technologies for channelling savings to investment, such as profit retention and the issue of shares and bonds in the capital market. The widely perceived government guarantee of bank deposits, and the important role played by state-owned banks for which the profit motive has been relatively unimportant, ${ }^{17}$ have certainly made a strong contribution to this dominancearguably, stronger than would have been optimal. Indonesia's crisis would not have been so severe were it not for the artificially expanded role of the banking system. In short, the better policy approach for the future will involve reducing or eliminating distortions that favour banking over other financial technologies, not maintaining or strengthening these distortions.

Elsewhere, the writer has proposed an approach to dealing with bank failures that implicitly accepts the view that protection of the value of bank deposits through guarantee/insurance schemes should not be seen as an appropriate objective of government policy but that, rather, the objective should be to minimise potential macroeconomic disturbance (McLeod 2004). In broad terms, this approach relies heavily on the market processes set in train when firms become insolvent, but focuses on accelerating those processes.

In 'normal' insolvencies, claims by creditors of the insolvent firm are typically put on hold until its future can be determined. At that point, creditors effectively become shareholders in the firm, and they share in the residual value of its assets (whether it is rehabilitated or liquidated). In the present context, the key aspect of the process is the long time lag from the moment an administrator is appointed to the insolvent firm until all financial issues are resolved. This is of crucial importance in the case of insolvent banks, since it is precisely the loss of liquidity on the part of banks'

17 State-owned banks in Indonesia have a collectively miserable record of failing and being recapitalised by the government, at tremendous cost to the public. They have played a far greater role in the economy than would have been possible if they had been subject to the unforgiving discipline of the market. 
creditors (especially their depositors) that generates the negative shock to the economy - which we wish to avoid. The proposed solution to this problem is for the bank supervision agency to appoint an administrator at the first sign of insolvency or even illiquidity on the part of the bank, and then immediately to impose a debtequity swap on all creditors to build up the capital of the bank sufficiently to attain the regulated minimum CAR. The size of this swap is based on a very rapidly undertaken, and conservative, audit of the bank's financial condition.

By this means, the bank is returned to good health (in the sense of meeting the minimal capital requirements) within just a few days, after which depositors have access to what remains of their deposits. They have also become shareholders in the bank, and are now free to sell their shares if they wish to generate additional liquidity. Since it is lack of access to demand deposits that provides the greatest threat to continuity of economic activity, it would be possible to treat the owners of such deposits as higher ranking creditors of the bank, such that the debt-equity swap could be restricted to the owners of time and savings deposits (assuming the total of these deposits is sufficient to cover the accumulated losses of the bank).

In short, once we set aside the ill considered notion that governments should protect the value of bank deposits, it is not difficult to design a set of arrangements for dealing with bank failures in such a way that macroeconomic disruption is minimised, and regressive transfers of wealth from the general public (especially the relatively poor who own very little amounts of bank deposits, if any) to bank depositors are avoided.

\section{CONCLUDING COMMENTS ON MARKETS AND INTERVENTIONISM}

The original guarantee funds of the late 1880s and early 1990s were described above as interventionist schemes introduced by paternalistic governments. If depositors had desired such guarantees sufficiently strongly to cover the cost of providing them, the market would have satisfied this demand, just as it satisfies the demand for insurance of houses and cars, for example. There is always a danger-indeed, it would seem inevitable-that when a demand for services is met through the political mechanism rather than through the market, the costs of provision will exceed the perceived benefits, so that some of the cost will need to be met by the general public rather than the recipients of the services in question. Thus the market processes that would otherwise ensure that roughly the optimal quantity of resources is devoted to these services is lost.

It is not surprising then that the record of the original deposit guarantee funds is largely a record of failure. Participation in some of these funds was voluntary, so 
banks that felt they were prudently managed, and that were able to assure their depositors of this, chose to stay outside the funds, thus avoiding paying the insurance premium (which they would otherwise have had to pass on to their depositors and borrowers). In turn, this meant that the funds found themselves covering the less prudently managed banks with a higher probability of failure. To the extent they increased the premium to match the risks they were covering the problem was exacerbated by adverse selection: more and more of the better managed banks left, leaving the funds covering a more and more risky portfolio. Eventually, many of these funds failed.

Perhaps to try to avoid this fate many of the guarantee funds were made compulsory. But when banks are obliged to pay for cover, it becomes rather difficult, politically, to allow the guaranteeing institution to set different insurance rates across banks (as they would if they were providing genuine, voluntarily purchased insurance) based on the perceived riskiness of each. Any attempt to impose relatively high premia on more risky banks would result in political pressure-such as complaints of 'unfair' treatment-to secure reductions. ${ }^{18}$ Thus the funds tended, or were required, to use the same rate for all banks, which meant that the natural tendency of genuine insurance schemes to penalise excessive risk-taking, and thus to reduce risk overall, was lost. On the contrary, risky behaviour was now being subsidised at the expense of more prudently managed banks, with the inevitable consequence that all banks tended to be managed in a more risky manner.

All of this may be interpreted as evidence that the strength of demand for deposit guarantees had been overestimated, relative to the cost of their provision, by the well-meaning governments in question. This is simply another illustration of the fact that governments are not very good at picking winners: in other words, the private sector is almost always better at perceiving genuine opportunities for making profits. It further reinforces the earlier argument that the Indonesian government has erred by taking on the role of guarantor of bank deposits. What is needed, rather, is for it to focus on the genuinely important issue: macroeconomic destabilisation as a consequence of bank failures. This deeply flawed deposit guarantee legislation fails to provide an appropriate solution.

18 Presumably it is for this reason that the new Indonesian legislation initially imposes a common guarantee premium for all banks, and restricts any future gap between the highest and lowest premium to just $1 \%$ p.a. 


\section{REFERENCES}

Demirgüç-Kunt, Asli, Baybars Karacaovali and Luc Laeven (2005), 'Deposit Insurance Around the World: A Comprehensive Database', World Bank Policy Research Working Paper 3628, June.

Djiwandono, J. Soedradjad (2004), 'Liquidity Support to Banks during Indonesia's Financial Crisis', Bulletin of Indonesian Economic Studies 40 (1): 59-75.

Enoch, Charles, Olivier Frécaut and Arto Kovanen (2003), 'Indonesia's Banking Crisis: What Happened and What Did We Learn?', Bulletin of Indonesian Economic Studies 39 (1): 75-92.

Fane, George (1998), 'The Role of Prudential Regulation', in Ross H. McLeod and Ross Garnaut (eds), East Asia in Crisis: From Being a Miracle to Needing One?, Routledge, London and New York.

Fane, George and Ross H. McLeod (2002), 'Banking Collapse and Restructuring in Indonesia, 1997-2001', Cato Journal, 22 (2) Fall: 277-95.

Frécaut, Olivier (2004), 'Indonesia's Banking Crisis: A New Perspective on \$50 Billion of Losses', Bulletin of Indonesian Economic Studies 40 (1): 37-57.

GOI (1997), Memorandum on Economic and Financial Policies, (Letter of Intent), Government of Indonesia, 31 October 1997, available at http://www.imf.org/external/np/loi/memo.

GOI (2004), Undang-undang Republik Indonesia Nomor 24 Tahun 2004 tentang Lembaga Penjamin Simpanan [Law No. 24/2005 of the Republic of Indonesia on a Deposit Guarantee Institution], 22 September.

Johnson, Colin (1998), 'Survey of Recent Developments', Bulletin of Indonesian Economic Studies 34 (2): 3-60.

Kenward, Lloyd R. (2004), 'Survey of Recent Developments', Bulletin of Indonesian Economic Studies 40 (1): 9-35.

Manning, Mark J. (2003), 'Finance Causes Growth: Can We Be So Sure?', Contributions to Macroeconomics, $4^{\text {th }}$ Quarter, 3 (1).

McLeod, Ross H. (2004), 'Dealing With Bank System Failure: Indonesia, 1997-2003', Bulletin of Indonesian Economic Studies 40 (1): 95-116. 
McLeod, Ross H. (2005a), 'The Economy: High Growth Remains Elusive', in Budy P. Resosudarmo (ed.), The Politics and Economics of Indonesia's Natural Resources, Indonesia Update Series, Institute of Southeast Asian Studies, Singapore: 31-50.

McLeod, Ross H. (2005b), 'Survey of Recent Developments, Bulletin of Indonesian Economic Studies 41 (2): 133-57.

Pangestu, Mari and Manggi Habir (2002), 'The Boom, Bust and Restructuring of Indonesian Banks', International Monetary Fund, Working Paper WP/02/66.

Soesastro, Hadi and Raymond Atje (2005), 'Survey of Recent Developments', Bulletin of Indonesian Economic Studies 41 (1): 5-34.

Sprague, Irvine H. (1986), Bailout: An Insider's Account of Bank Failures and Rescues, Basic Books, New York.

Thies, Clifford F. and Daniel A. Gerlowski (1989), 'Deposit Insurance: A History of Failure', Cato Journal 8 (3), Winter: 677-93. 